\title{
Antioxidant and Cytotoxic Activities and Chemical Profile of Five Amaranthaceae Plants Collected in the South of Brazil
}

\section{Wallace Ribeiro Correa ${ }^{1,2}$, Alvaro Jose Hernandez Tasco ${ }^{1 *}$, Jane VN Marinho ${ }^{1}$, Aislan CRF Pascoal ${ }^{1}$, Joao Ernesto de Carvalho ${ }^{3}$, Maria Salete Marchioretto ${ }^{4}$ and Marcos Jose Salvador ${ }^{1}$}

${ }^{1}$ Institute of Biology, Department of Plant Biology, PPG-BTPB, University of Campinas (UNICAMP), 13083-970, Campinas, SP, Brazil

${ }^{2}$ Federal Institute of Education, Science and Technology, South of Minas Gerais, Praça Tiradentes, 416, Inconfidentes, 37576-000 Minas Gerais, Brazil

${ }^{3}$ CPQBA/UNICAMP, Rua Alexandre Cazelatto, 999, 13081-970, Vila Betel, Paulinia, SP, Brazil

${ }^{4}$ Herbarium PACA/IAP-UNISINOS, Rua Brasil, 725, 93001-970, São Leopoldo, Rio Grande do Sul, Brazil

\begin{abstract}
In this study, the antioxidant and cytotoxic activity, the phenolic content and the HPLC-DAD/ESI-MS profile of the ethanolic extracts of five Amaranthaceae plants collected in the south of Brazil were investigated: these were Alternanthera philoxeroides (Mart.) Griseb. (I), Alternanthera hirtula (Mart.) R.E. Fr. (II), Alternanthera praelonga A. St. -Hil. (III), Froelichia tomentosa (C. Mart.) Moq. (IV) and Pfaffia tuberosa (Spreng.) Hicken (V). The antioxidant potential was determined using the DPPH and ORAC-FL assays. The total phenolic content was measured using the FolinCiocalteu reagent. The ethanolic extracts of I, II, IV and V showed high levels of phenolic compounds (3.6-20.0 mg $\mathrm{GAE} / \mathrm{Kg}$ ), as well as high antioxidant activity in both methods. The cytotoxicity of the extracts was investigated in vitro against panel of human cancer cell lines and against VERO control. The extract of $\mathrm{V}$ exhibited anti-proliferative activity against all cancer cell lines studied (Total Growth Inhibition, TGI<100 $\mu \mathrm{g} / \mathrm{mL}$ ), except for VERO cell line (TGI=125.2 $\mu \mathrm{g} /$ $\mathrm{mL}$ ). HPLC-UV/DAD and ESI-MS analyses revealed that the extracts investigated appear to contain phenolic acids and flavonoids as main constituents. Findings from this study demonstrated that the extracts of the Amaranthaceae plants from the south of Brazil may be considered as promising sources of antioxidant and anti-proliferative compounds.
\end{abstract}

Keywords: Amaranthaceae; Anti-proliferative activity; Antioxidant capacity; Phenolic

\section{Introduction}

Free radicals are responsible for lipid peroxidation occurring during production and storage of nutrients and are directly involved in some cancers, cardiovascular disorders, diabetes, Alzheimer's disease, and others human pathologies [1,2]. Antioxidant compounds can be useful to prevent several degenerative diseases or as preservative in food, toiletries and pharmaceutical products [3-7]. Species of the Amaranthaceae family are able to accumulate phenolic substances and these are closely related to the antioxidant activity due to their capacity to scavenge free radicals, protect against lipid peroxidation and quench reactive oxygen species $[3-5,8,9]$. Members of this plant family are used in the extraction of natural pigments for application as food colorants and antioxidants $[1,4,5]$. In addition, species of Amaranthaceae have been used in Brazilian folk medicine for the treatment of diseases such as infections and inflammation [10-15].

Previous chemical analyses of Amaranthaceae plants have demonstrated the occurrence of phenolic acids, aurones, betacyanins, betalains, betaxanthins, chromoalkaloids, ecdysteroids, flavonoids, protoalkaloids, saponins, steroids, and triterpenes [1,2,4,11-15].

These facts prompted us to investigate the chemical composition and antioxidant and cytotoxic activities of the ethanolic extracts of five Amaranthaceae plants collected in the south of Brazil; these were A. philoxeroides (Mart.) Griseb. (I), A. hirtula (Mart.) R.E. Fr. (II), A. praelonga A. St. -Hil. (III), F. tomentosa (C. Mart.) Moq. (IV) and P. tuberosa (Spreng.) Hicken (V).

\section{Materials and Methods}

\section{Plant material}

The whole plants of A. philoxeroides (Mart.) Griseb. (I), A. hirtula (Mart.) R.E. Fr. (II), A. praelonga A. St. -Hil. (III), F. tomentosa (Mart.) Moq. (IV) and P. tuberosa (Spreng.) Hicken (V) were collected in Rio Grande do Sul State, Brazil. Voucher specimens were deposited at the herbarium PACA/IAP-UNISINOS, RS, Brazil, register number PACA
103073, PACA 103235, PACA 103233, PACA 103236 and PACA 103234 for plants I, II, II, IV and V, respectively.

\section{Extracts preparation and chemical analysis}

Dried and powdered leaves of each plant $(50 \mathrm{~g})$ were extracted with ethanol $(3 \times 300 \mathrm{~mL})$ at room temperature. The solvent was removed under reduced pressure to give the crude extracts. Phytochemical tests for sterols/triterpenes, phenolic compounds, tannins, saponins, and alkaloids were carried out according to usual methodology [16].

\section{Quantitative determination of total soluble phenols}

The extracts, dissolved in methanol, were analyzed for their total soluble phenolic content according to the Folin-Ciocalteau colorimetric method [17], using gallic acid as reference. The results were expressed as mg of gallic acid equivalents (GAE) per g of extract or fraction (mg of GAE/g). The analyses were performed in triplicate.

\section{Radical scavenging activity using the DPPH method}

The antiradical activity of extracts was determined using the stable 2,2-diphenyl-1-picrylhydrazyl radical (DPPH) [18]. The test was performed in 96 -well microplates. Fifty $\mu \mathrm{L}$ of a $250 \mu \mathrm{M}$ DPPH solution in $\mathrm{MeOH}$ was added to a range of solutions of different concentrations (7 serial 3-fold dilutions to give a final range of 100 to $1.6 \mu \mathrm{g} \mathrm{mL} \mathrm{L}^{-1}$ ) of extracts to be tested in $\mathrm{MeOH}(10 \mu \mathrm{L})$. Absorbance at $517 \mathrm{~nm}$ was

*Corresponding author: Hernandez Tasco AJ, Institute of Biology, Department of Plant Biology, PPG-BTPB State University of Campinas (UNICAMP), 13083-970, Campinas, SP, Brazil, Tel: 551935211174; E-mail: alvarojoseht@gmail.com

Received June 10, 2016; Accepted June 29, 2016; Published July 03, 2016

Citation: Correa WR, Tasco AJH, Marinho JVN, Pascoal ACRF, Carvalho JE et al. (2016) Antioxidant and Cytotoxic Activities and Chemical Profile of Five Amaranthaceae Plants Collected in the South of Brazil. Nat Prod Chem Res 4: 230. doi:10.4172/2329-6836.1000230

Copyright: (c 2016 Correa WR, et al. This is an open-access article distributed under the terms of the Creative Commons Attribution License, which permits unrestricted use, distribution, and reproduction in any medium, provided the original author and source are credited. 
determined 30 min after the addition of each of the compounds tested, and the percentage of activity was calculated. The pure compounds quercetin, vitexin, caffeic acid, chlorogenic acid from Sigma-Aldrich were also tested and 6-hydroxy-2,5,7,8-tetramethylchroman-2carboxylic acid (Trolox) from Sigma-Aldrich was used as positive control. All samples were tested in triplicate. The antioxidant activity of each sample was expressed as the $\mathrm{SC}_{50}$ value, which is the concentration in $\mu \mathrm{g} \mathrm{mL}^{-1}$ of each extract that scavenged $50 \%$ of the DPPH radicals. All of the results are expressed as the mean of 3 different trials.

\section{Evaluation of antioxidant capacity by ORAC assay}

The antioxidant capacity of the ethanolic extract by oxygen radical absorbance capacity (ORAC) kinetic assay, was carried out according to the method established by $\mathrm{Ou}$ and co-workers [19,20], with modifications [4]. The data were expressed as $\mu$ moles of 6-hydroxy2,5,7,8-tetramethylchroman-2-carboxylic acid (Trolox) equivalents (TE) per $g$ of the the extract on a dry weight basis $(\mu \mathrm{mol}$ of $\mathrm{TE} / \mathrm{g}$ ) and as relative Trolox equivalent for pure compounds. Quercetin, vitexin, caffeic acid and chlorogenic acid from Sigma-Aldrich were also tested. The analyses were performed in triplicate.

\section{HPLC-DAD/ESI-MS analyses}

Crude extracts of Amaranthaceae plants were diluted in a solution containing 50\% (v/v) chromatographic grade methanol and $50 \%(\mathrm{v} / \mathrm{v})$ deionized water and $0.5 \%$ ammonium hydroxide. In the fingerprinting ESI-MS analysis, the general conditions were: source temperature $100^{\circ} \mathrm{C}$, capillary voltage $3.0 \mathrm{kV}$ and cone voltage $30 \mathrm{~V}$. For measurements in the negative ion mode, ESI(-)-MS, $10.0 \mu \mathrm{L}$ of concentrated $\mathrm{NH}_{4} \mathrm{OH}$ was added to the sample mixture having a total volume of $1000 \mu \mathrm{L}$ yielding $0.1 \%$ as a final concentration. ESI-MS was performed by direct infusion with a flow rate of $10 \mu \mathrm{L} \mathrm{min} \mathrm{mL}^{-1}$ using a syringe pump. Structural analysis of single ions in the mass spectrum of each extract was performed by ESI-MS/MS. The ion with the $\mathrm{m} / \mathrm{z}$ of interest was selected and submitted to $15-45 \mathrm{eV}$ collisions with argon in the collision quadrupole. The compounds were identified by comparison of their ESI-MS/MS fragmentation spectra with literature data [4,8,21-23]. HPLC analyses were conducted using an RP-18 column (Lichrospher, $5 \mu \mathrm{m}, 225 / 4.6 \mathrm{~mm}$, Merck). The mobile phase consisted of a linear gradient combining solvent A (acetonitrile) and solvent B (water/acetic acid, 99:1, v/v, $\mathrm{pH} 2.88$ ) as follows: $15 \% \mathrm{~A}(15$ $\mathrm{min}), 15-20 \% \mathrm{~A}(7 \mathrm{~min}), 20 \% \mathrm{~A}(5 \mathrm{~min}), 20-40 \% \mathrm{~A}(5 \mathrm{~min}), 40 \% \mathrm{~A}(5$ $\mathrm{min}), 40-15 \% \mathrm{~A}(3 \mathrm{~min})$. The analyses were carried out in triplicate at a flow rate of $0.8 \mathrm{~mL} / \mathrm{min}$ and an injection volume of $20 \mu \mathrm{L}$. The UVDAD detector was set to record between 200 and $600 \mathrm{~nm}$, and the UV chromatograms were measured at 254 and $330 \mathrm{~nm}$. The samples were the crude extract and vitexin standard (Sigma-Aldrich) at $1 \mathrm{mg} / \mathrm{mL}$.

\section{Cytotoxicity assay}

It was used the U251 (glioma, CNS), UACC-62 (melanoma), MCF-7 (breast), NCI-ADR/RES (ovarian-resistant), 786-0 (kidney), NCI-H460 (lung, no small cells), PC-3 (prostate), OVCAR-3 (ovarian), HT-29 (colon), and VERO (no cancer) cell lines. The extracts of the five Amaranthaceae plants studied and the compounds detected in the extracts quercetin, vitexin and caffeic acid (from Sigma-Aldrich) were assayed. The assay was done as described previously [24]. Briefly, the cells were distributed in 96 well plates $(100 \mu \mathrm{L}$ cells/well $)$ and exposed to various concentrations of samples $(0.25,2.5,25.0$ and $250.0 \mu \mathrm{g} / \mathrm{mL})$ in DMSO $(0.1 \%)$ at $37^{\circ} \mathrm{C}$, with $5 \%$ of $\mathrm{CO}_{2}$, for $48 \mathrm{~h}$. The final concentration of DMSO did not affect the cell viability. A $50 \%$ trichloroacetic acid solution was added and after incubation for 30 $\min$ at $4^{\circ} \mathrm{C}$, the cells were washed and dried. Cell proliferation was determined by spectrophotometric quantification (at $540 \mathrm{~nm}$ ) of the cellular protein content using sulphorodamine B. The experiments were carried, at least, in triplicate and the concentration necessary to total growth inhibition (TGI) was calculated in $\mu \mathrm{g} / \mathrm{mL}$. Doxorubicin was used as positive control.

\section{Statistical analysis}

Data are reported as mean (\%RSD, relative standard deviation) of triplicate determinations. The statistical analyses were carried out using the Microsoft Excel 2010 software package (Microsoft Corp., Redmond, WA).

\section{Results}

\section{Antioxidant analysis}

Some of the samples exhibited antioxidant activity that was concentration-dependent in $\mathrm{DPPH}$ assays, with $\mathrm{SC}_{50}$ values varying from 12.5 to $150.2 \mu \mathrm{g} / \mathrm{mL}$. In DPPH assays the highest antioxidant activity was exhibited by the ethanol extract of the whole plant of P. tuberosa $\left(\mathrm{SC}_{50}=11.5 \mu \mathrm{g} / \mathrm{mL}\right)$, followed by extracts of $F$. tomentosa $\left(\mathrm{SC}_{50}=43.6 \mu \mathrm{g} / \mathrm{mL}\right)$, and A. Philo Xero ides $\left(\mathrm{SC}_{50}=150.2 \mu \mathrm{g} / \mathrm{mL}\right)$. In comparison with pure compounds, the $\mathrm{SC}_{50}$ of the extract of $P$. tuberosa was more active than chlorogenic acid and similar to that of caffeic acid (Table 1). Moreover, in the ORAC-FL kinetic assay, the extracts showed good antioxidant capacity with values between 291.0 and $6403.0 \mu \mathrm{mol}$ of Trolox equivalents per gram of extract ( $\mu \mathrm{mol}$ of TE/g). In ORACFL assays, the highest antioxidant activity was exhibited by the ethanol extract of the whole plant of $F$. tomentosa, followed by extracts of $P$. tuberosa, A. philoxeroides and A. hirtula. The ethanolic extract of $A$. praelonga showed small antioxidant capacity in both the DPPH and ORAC-FL assays (Table 1).

Thus, the results documented in this study demonstrate that some of the extracts analyzed showed antioxidant capacity (measured by DPPH and ORAC assays) and this activity correlates with the total phenolic content (measured by FCR assay). Moreover, the isolated compounds caffeic acid, quercetin and vitexin showed considerable antioxidant capacity (Table 1) and were detected in some of the studied species.

\begin{tabular}{|c|c|c|c|}
\hline $\begin{array}{c}\text { Sample } \\
\text { Ethanol extract }\end{array}$ & $\begin{array}{c}\text { Phenol } \\
\text { content }^{\mathrm{a}} \\
\text { (mg of }^{(\mathrm{mg} / \mathrm{g})^{\mathrm{b}}}\end{array}$ & $\begin{array}{c}\text { DPPH assay, } \\
\text { SC }_{50}^{a} \\
(\mu \mathrm{g} / \mathrm{mL})^{\mathrm{c}}\end{array}$ & $\begin{array}{l}\text { ORAC assay } \\
(\mu \mathrm{mol} \text { of } \\
\mathrm{TE} / \mathrm{g})^{\mathrm{d}}\end{array}$ \\
\hline Alternanthera philoxeroides (I) & $<3.6$ & $150.2(1.2)$ & $1019.2(2.4)$ \\
\hline Alternanthera hirtula (II) & $3.6(1.2)$ & $>200.0$ & $897.0(1.5)$ \\
\hline Alternanthera praelonga (III) & $<3.6$ & $>200.0$ & $291.0(2.2)$ \\
\hline Froelichia tomentosa (IV) & $20.0(2.5)$ & $43.6(2.1)$ & $6403.0(2.6)$ \\
\hline Pfaffia tuberosa (V) & $17.2(1.4)$ & $11.5(1.8)$ & $1830.2(2.4)$ \\
\hline Quercetin & - & $8.3(2.1)$ & $5.6(0.9)^{e}$ \\
\hline Vitexin & - & $18.5(3.1)$ & $1.0(1.2)^{\mathrm{e}}$ \\
\hline Caffeic acid & - & $11.2(2.4)$ & $2.9(2.0)^{e}$ \\
\hline Chlorogenic acid & - & $12.8(1.5)$ & $2.6(1.5)^{\mathrm{e}}$ \\
\hline Trolox* & - & $3.8(1.8)$ & - \\
\hline
\end{tabular}

a Mean value (\%RSD, relative standard deviation) of triplicate assays. ${ }^{\mathrm{b} T o t a}$ phenolics data expressed as $\mathrm{mg}$ of gallic acid equivalents per $\mathrm{g}$ (mg of GAE/g). 'DPPH assay data expressed as $\mathrm{SC}_{50}$ (concentration that inhibited $50 \%$ of the DPPH radical) in $\mu \mathrm{g}$ per $\mathrm{mL}$. 'ORAC data expressed as $\mu \mathrm{mol}$ of Trolox equivalents per $\mathrm{g}\left(\mu \mathrm{mol}\right.$ of TE/g). ${ }^{\circ} \mathrm{ORAC}$ data expressed as relative Trolox equivalent, mean (\%RSD, relative standard deviation) of triplicate assays. "Experimental positive control. -: not evaluated.

Table 1: Total phenol content and antioxidant capacity by the DPPH and ORAC assays of ethanol extracts of Amaranthaceae species. 


\section{Cytotoxicity assay}

Moreover, we also show that extracts of Amaranthaceae plants were able to inhibit cell growth tumor (Table 2). Our results demonstrated that the extracts of Amaranthaceae, mainly in the plants IV and V, exhibited anti-proliferative activity against human cancer cell lines studied (Total Growth Inhibition, TGI $<100 \mu \mathrm{g} / \mathrm{mL}$ ) and have no cytotoxicity against VERO cell line (TGI $\geq 125.2 \mu \mathrm{g} / \mathrm{mL}$ ). Our results demonstrated that $P$. tuberosa exhibited anti-proliferative activity against all human cancer cell lines studied (Total Growth Inhibition, $\mathrm{TGI}<100 \mu \mathrm{g} / \mathrm{mL}$ ), except for VERO no cancer cell line (TGI $=125.2 \mu \mathrm{g} /$ $\mathrm{mL}$ ), promissory study indicating a future for the species.

\section{HPLC-DAD/ESI-MS analyses}

The ESI-MS fingerprint technique with direct infusion [21-23] was used to characterize the presence of compounds with antioxidant capacity in this work. The extracts were analyzed by direct insertion in the negative ion mode as this method is sensitive and selective for the identification of polar organic compounds with acidic sites, such as phenolic organic acids. Deprotonated forms of the compounds of interest were then selected, dissociated and their ESI-MS/MS were compared with those of standards. The compounds were identified by comparison of their ESI-MS/MS fragmentation spectra with fragmentation spectra of the authentic standard samples and with literature data $[4,21]$. These analyses showed that some of constituents in the analyzed samples coincided with the mass and ESI-MS/MS fragmentation spectra of phenolic acids and flavonoids, suggesting presence of these compounds in the some of analyzed plants (Table 3; Figures 1 and 2).

To confirm the presence of the flavonoid vitexin, HPLC-UV/DAD analyses of standards samples of flavonoids glycosides and of the crude extract were performed. A peak was produced with a retention time coincident with the standard sample and with the same absorption spectrum in the UV/DAD analysis. Moreover, the identity of vitexin in Alternanthera samples plant I and II were confirmed through coelution with an authentic standard sample (Figure 3 ).

\section{Discussion}

Amaranthaceae has been reported as one of the many vegetables rich in antioxidant $[2-4,8]$. The study showed that the extracts from Amaranthaceae plants collected in the south of Brazil, present antioxidant activity. In accordance with literature data, samples with values $\geq 1000.0 \mu \mathrm{mol}$ of TE/g can be considered to have good antioxidant capacity in this assay $[19,20]$.
The isolated compounds caffeic acid, quercetin and vitexin showed considerable antioxidant capacity (Table 1) and were detected in some of the studied species (Table 2), for example in F. tomentosa, and $P$. tuberosa that showed the best antioxidant activity in DPPH and ORAC-FL assays.

The differences in the antioxidant capacity of the species studied between the two assays is due to differences in sensitivity of the chemical reactions involved in each test and/or showing correlation with concentration in the antioxidant agents in the matrix: ORAC is a hydrogen atom transfer reaction based assay (HAT) and DPPH is a single electron transfer reaction based assay (ET). It is apparent that the hydrogen atom transfer reaction is a key step in the radical chain reaction. Therefore, the HAT based method is more relevant to the radical chain-breaking antioxidant capacity [20].

Phenolic compounds have been presented as important compounds in combating free radical production mainly due to their chemical structure and redox capacity, allowing them to act as reducing agents, hydrogen donating, neutralizing free radicals [25,26], chelating of transition metals and inhibiting lipid peroxidation [27]. In addition, these compounds in biological systems possess pharmacological properties, acting as preventative agents against diseases related to oxidative stress $[26,28]$.

In this study, phytochemical screening showed the presence of triterpenes/sterols and phenolic compounds in all samples. These results are in agreement with previous reports of flavonoids $[4,8,11]$, triterpenes [15] and phenolic compounds [1] in Amaranthaceae species in the genera Alternanthera, Pfaffia and Froelichia $[4,5,8,15,29]$ and with the HPLC-DAD/ESI-MS profile of these five Amaranthaceae plants studied (Table 3; Figures 1-3). Thus, direct infusion electrospray ionization mass spectrometry (ESI-MS) and HPLC-DAD analyses provided important information about bioactive components present in the Amaranthaceae extracts that are widely reported as potent antioxidants, probably explaining the antioxidant activity of the studied extracts $[3-5,8]$. The isolated compounds caffeic acid, quercetin and vitexin showed considerable antioxidant capacity (Table 1) and were detected in some of the studied species with similar results documented in the literature data $[4,8,26,30]$.

However, analysis by ESI-MS is dependent on the ionization capacity of these substances in the sample, the concentration of these molecules in the matrix and the complexity of the matrix. Thus, it is not always possible only by this analytical technique has the necessary security to get the identity of all the constituents of a sample. For to extend the analytical security is possible the used of chromatographic techniques associated with universal

\begin{tabular}{|c|c|c|c|c|c|c|}
\hline \multicolumn{7}{|c|}{ TGI $(\mu \mathrm{g} / \mathrm{mL})^{\mathrm{b}}$} \\
\hline \multirow[t]{2}{*}{ Cell lines $^{a}$} & $\begin{array}{l}\text { Alternanthera hirtula } \\
\text { (I) }\end{array}$ & $\begin{array}{c}\text { Alternanthera } \\
\text { philoxeroides(II) }\end{array}$ & $\begin{array}{l}\text { Alternanthera } \\
\text { praelonga (III) }\end{array}$ & $\begin{array}{c}\text { Froelichia tomentosa } \\
\text { (IV) }\end{array}$ & $\begin{array}{c}\text { Pfaffia } \\
\text { tuberosa (V) }\end{array}$ & \multirow[t]{2}{*}{ Doxorubicin } \\
\hline & Ext EtOH & Ext EtOH & Ext EtOH & Ext EtOH & Ext EtOH & \\
\hline $\mathbf{u}$ & $>250$ & $>250$ & 43.21 & 39.92 & $>250$ & 0.51 \\
\hline m & $>250$ & $>250$ & 73.58 & 13.73 & $>250$ & 0.29 \\
\hline 7 & $>250$ & $>250$ & $>250$ & 55.60 & $>250$ & 1.27 \\
\hline 4 & $>250$ & $>250$ & $>250$ & 83.22 & $>250$ & 4.13 \\
\hline$p$ & $>250$ & $>250$ & $>250$ & 31,45 & $>250$ & 0.78 \\
\hline 0 & $>250$ & $>250$ & $>250$ & 100.8 & $>250$ & 3.60 \\
\hline h & $>250$ & $>250$ & $>250$ & 92.81 & $>250$ & $>25$ \\
\hline k & 29.39 & 9.51 & 30.52 & 3.46 & 0.42 & 0.05 \\
\hline $\mathbf{v}$ & $>250$ & $>250$ & $>250$ & 125.2 & $>250$ & 11.28 \\
\hline
\end{tabular}

aHuman cancer cell lines: u=UACC-62 (melanoma); m=MCF-7 (mamma); 7=786-O (kidney); 4=NCl-H460 (lung); p=PC-3 (prostate); o=OVCAR-3 (ovary); h=HT-29 (colon); k=K562 (leukemia). Non cancer cell line: v: VERO (epithelial cell from green monkey kidney). ${ }^{\text {}}$ TGI: Total Growth Inhibition - concentration that inhibited cell growth by $100 \%$.

Table 2: Concentration of extracts from Amaranthaceae plants able to inhibit total cell growth. 
MS 146 (0.339) Sm (Mn, 2×0.75); Cm (29:75)

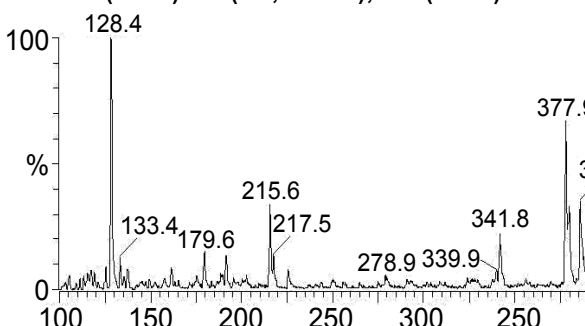

MS 244 (0.325) Sm (Mn, 2×0.75); Cm (26:85)

$100-128.5$

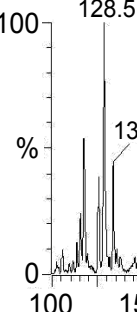

(1)

\section{9}

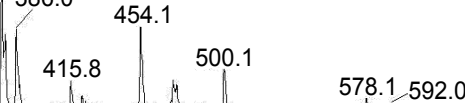

MS 344 (0.325) Sm (Mn, 2×0.75); Cm (27:93)

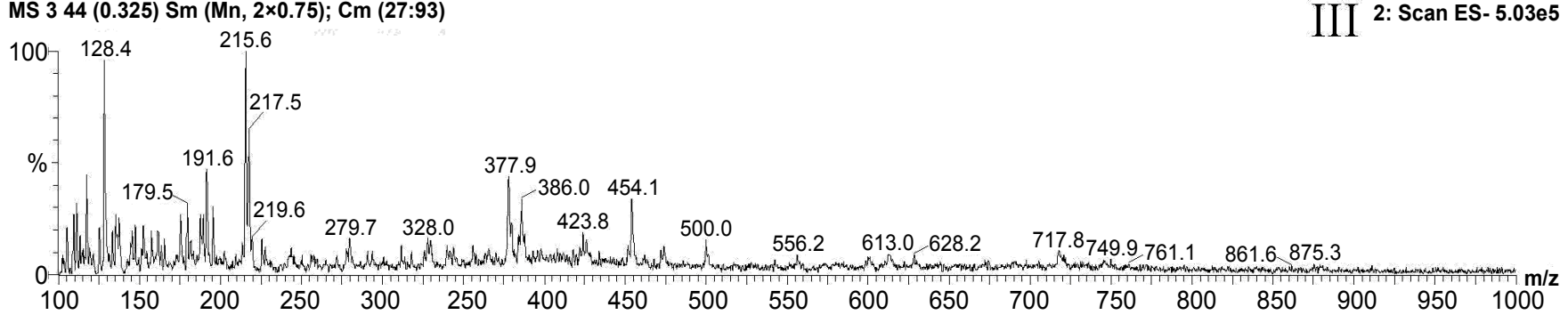

MS 446 (0.339) Sm (Mn, 2×0.75); Cm (25:86)

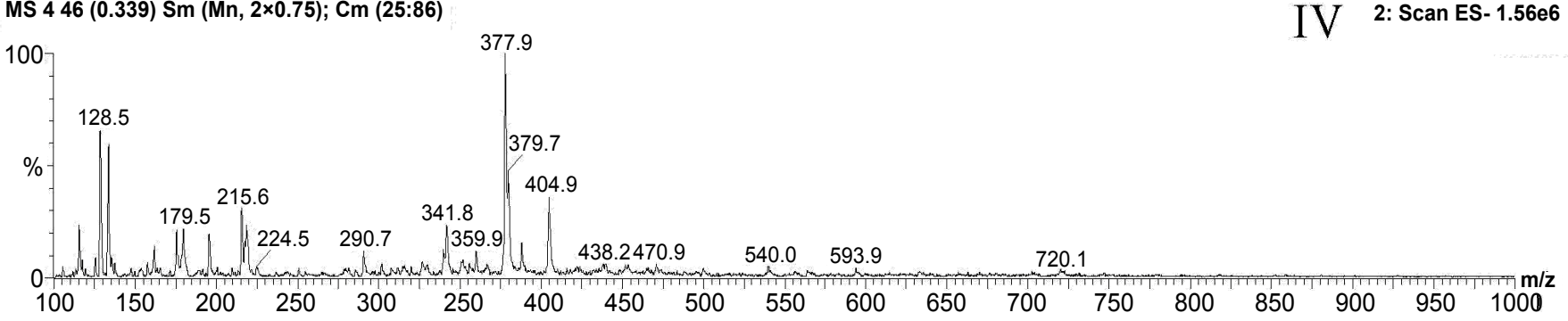

MS 545 (0.333) Sm (Mn, 2×0.75); Cm (27:93)

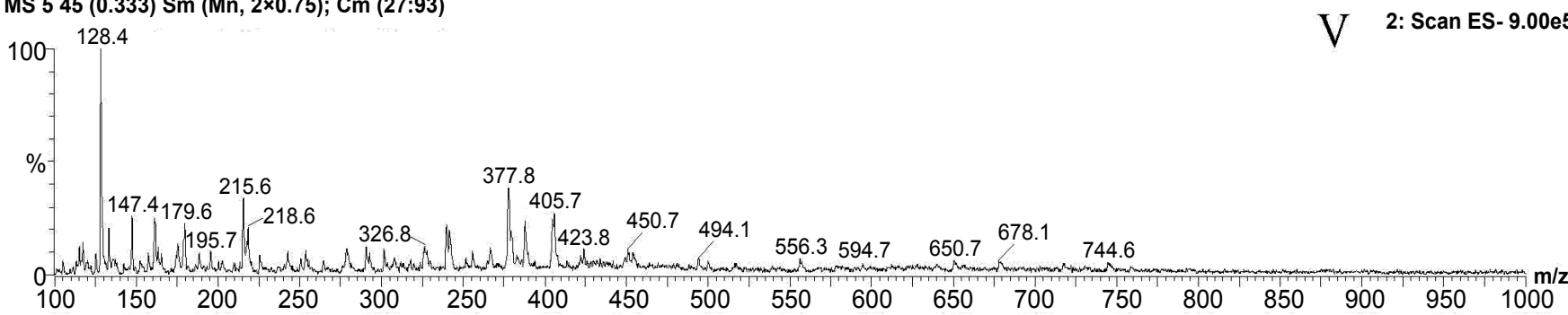

Figure 1: ESI-MS fingerprints of ethanol extracts from five Amaranthaceae whole plants from the south of Brazil (I: Alternanthera philoxeroides, II: Alternanthera hirtula, III: Alternanthera praelonga, IV: Froelichia tomentosa, and V: Pfaffia tuberosa). 
<smiles>COc1cc(/C=C/C(=O)O)ccc1O</smiles>

Figure 2: Compounds identified in ethanol extracts from Amaranthaceae plants of the South of Brazil.

\begin{tabular}{|c|c|c|c|c|c|c|c|}
\hline \multicolumn{8}{|c|}{ ESI-MS ions $(\mathrm{m} / \mathrm{z})$} \\
\hline \multirow[t]{2}{*}{ Compound } & \multirow[b]{2}{*}{ I } & \multicolumn{4}{|c|}{$\begin{array}{l}\text { Amaranthaceae } \\
\text { plants }\end{array}$} & \multirow[t]{2}{*}{$\begin{array}{c}\text { Deprotonated ions } \\
{[\mathrm{M}-\mathrm{H}] \mathrm{m} / \mathrm{z}}\end{array}$} & \multirow[t]{2}{*}{ MS/MS ions $m / z$} \\
\hline & & II & III & IV & $\mathbf{v}$ & & \\
\hline Malic acid & + & + & - & + & + & 133 & $15 \mathrm{eV}: 133 \rightarrow 115$ \\
\hline Caffeic acid & + & + & + & + & + & 179 & $15 \mathrm{eV}: 179 \rightarrow 125$ \\
\hline Quinic acid & + & + & + & + & + & 191 & $\begin{array}{c}25 \mathrm{eV}: 191 \rightarrow 173,127 \\
111,93,85\end{array}$ \\
\hline Ferulic acid & - & + & + & + & + & 195 & 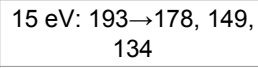 \\
\hline Quercetin & - & + & - & + & + & 301 & $15 \mathrm{eV}: 301$ \\
\hline Vitexin & $+/-$ & $+/-$ & $+/-$ & - & - & 431 & $15 \mathrm{eV}: 431$ \\
\hline
\end{tabular}

Legend: +: detected; -: not detected; +/-: possible presence (I: Alternanthera philoxeroides, II: Alternanthera hirtula, III: Alternanthera praelonga, IV: Froelichia tomentosa, and V: Pfaffia tuberosa)

Table 3: Compounds identified in ethanol extracts from five Amaranthaceae species from the south of Brazil using ESI(-)-MS/MS analyses.

detection systems, resources joining separation of sample constituents and the spectrum peak of each chromatography such as HPLC-UV/DAD and HPLC-MS. In This study was what happened to the vitexin flavonoid that showed low ionization capacity in the analysis of conditions for ESI-MS, leaving doubts as to ion detection with $m / z 431$ in the samples of plants I, II and III, but it was possible to confirm their presence with the analysis by HPLC-UV/DAD with the standard sample authentic employment in plants I and II. The presence of C-glycoside flavones in plants of the genus Alternanthera is documented in literature data $[4,8]$. In the case of the sample of plant III it was not possible to confirm the presence of vitexin flavonoid in the analysis of conditions by ESI-MS and HPLC-UV/DAD, and this flavonoid may be present in the sample but in a concentration below the limit of detection in the HPLC-UV/DAD analysis.

Extracts of Amaranthaceae plants were able to inhibit cell growth tumor. These results indicate good anti-proliferative effect for these plants and suggest the potential of Amaranthaceae plants as a preventive agent against cancer and as source of bioactive compounds [31,32]. The EtOH extracts of A. hirtula (I), A. philoxeroides (II) and $P$. tuberosa $(\mathrm{V})$ exhibited selective antiproliferative activity for $\mathrm{K} 562$ (leukemia) cancer cell line, with TGI varying of $9.51-30.52 \mu \mathrm{g} / \mathrm{mL}$ and no demonstrated toxicity against VERO cell (non cancer cell, epithelial cell from green monkey kidney, TGI $>250 \mu \mathrm{g} / \mathrm{mL}$ ). On the other hand, the EtOH extract of F. tomentosa showed cytotoxicity against all the cell lines tested, including to VERO cell line (TGI=125.2 $\mu \mathrm{g} / \mathrm{mL}$ ). Flavonoids and phenolic acids were identified in these bioactive extracts and anticancer activities have been reported for these compounds. The antitumor activity of vitexin, quercetin and caffeic acid were previously observed against leukemic cell line [30,33,34]. Zhou et al. documented that vitexin-induced cytotoxic effect is through the induction of apoptosis, which is mediated by activation of caspases 
Citation: Correa WR, Tasco AJH, Marinho JVN, Pascoal ACRF, Carvalho JE, et al. (2016) Antioxidant and Cytotoxic Activities and Chemical Profile of Five Amaranthaceae Plants Collected in the South of Brazil. Nat Prod Chem Res 4: 230. doi:10.4172/2329-6836.1000230

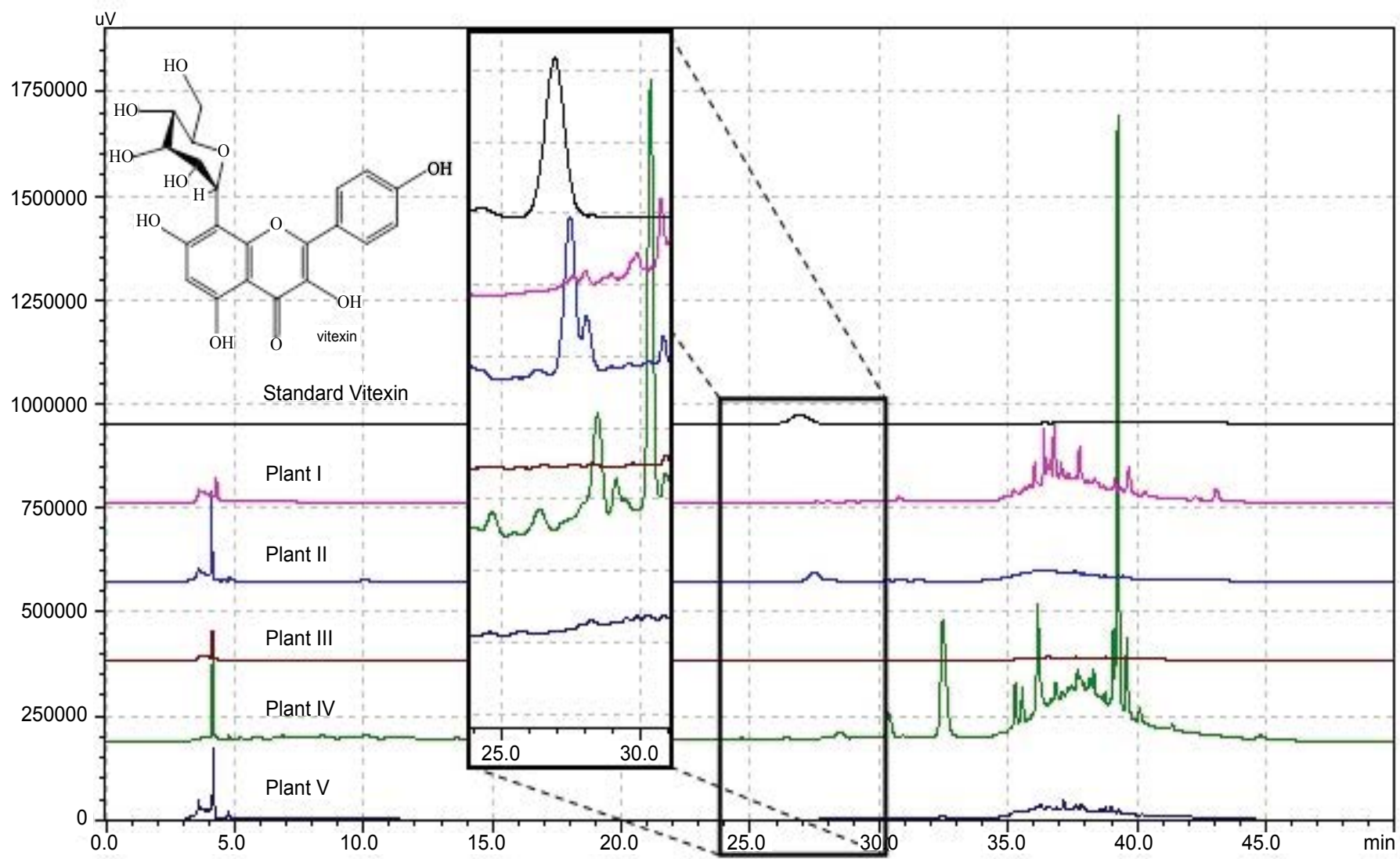

Figure 3: HPLC chromatograms of the ethanol extract for identifying of the flavonoid vitexin: plant I: Alternanthera philoxeroides, plant II: Alternanthera hirtula, plant III: Alternanthera praelonga, plant IV: Froelichia tomentosa, and plant V: Pfaffia tuberosa.

[35]. Therefore, the presence of these compounds in these bioactive extracts of Amaranthaceae plants may be responsible, at least in part, for antioxidant and cytotoxic activities observed.

\section{Conclusions}

In summary, in this study, ethanolic extracts of five Amaranthaceae plants collected in the south of Brazil showed high levels of phenolic compounds, as well as high antioxidant activity and promising cytotoxic activity against some cancer cell lines and may be considered as promising sources of antioxidant and anti-proliferative compounds, such as phenolic acids and flavonoids. This is the first report of the antioxidant and anti-proliferative activities of the ethanoic extracts form whole plants, suggest that species are a rich source of biologically active compounds. Further studies to confirm the identity of detected compounds and investigating the role of these extracts and constituents in biological systems are necessary to better define their potential therapeutic and preventive uses against ROS-dependent chronic diseases and as a source of cytotoxic agent useful for in vivo applications in cancer treatment.

\section{Acknowledgements}

The authors are grateful to FAPESP (Proc. 2006/06079-4; 2009/05992-6; 2010/11426-3; 2012/09031-3), CNPq, CAPES, FAPEAM and FAEPEX-UNICAMP for financial support.

\section{References}

1. Norazaidah AY, Hainida EKI (2006) Antioxidant activity and phenolic content of raw and blanched Amaranthus species. Food Chem 94: 47-52.
2. Roriz CL, Barros L, Carvalho AM, Santos-Buelga C, Ferreira ICFR (2014) Pterospartum tridentatum, Gomphrena globosa and Cymbopogon citratus: A phytochemical study focused on antioxidant compounds. Food Res I 62: 684-693.

3. Wang P, Li S, Ownby S, Zhang Z, Yuan W, et al. (2009) Ecdysteroids and a sucrose phenylpropanoid ester from Froelichia floridana. Phytochemistry 70 : 430-436.

4. Salvador MJ, Ferreira EO, Mertens-Talcott SU, De Castro WV, Butterweck V et al. (2006) Isolation and HPLC quantitative analysis of antioxidant flavonoids from Alternanthera tenella Colla. Z Naturforsch C 61: 19-25.

5. Cai $Y$, Sun M, Corke $H$ (2003) Antioxidant activity of betalains from plants of the amaranthaceae. J Agric Food Chem 51: 2288-2294.

6. Li H, Deng Z, Liu R, Zhu H, Draves J, et al. (2015) Characterization of phenolics, betacyanins and antioxidant activities of the seed, leaf, sprout, flower and stalk extracts of three Amaranthus species. J Food Compos Anal 37: 75-81.

7. Liu H, Cao J, Jiang W (2015) Evaluation of physiochemical and antioxidant activity changes duringfruit on-tree ripening for the potential values of unripe peaches. Sci Horticult 193: 32-39.

8. Souza JG, Tomei RR, Kanashiro A, Kabeya LM, Azzolini AECS, et al. (2007) Ethanolic crude extract and flavonoids isolated from Alternanthera maritima: neutrophil chemiluminescence inhibition and free radical scavenging activity. $Z$ Naturforsch C 62: 339-347.

9. Kumar G, Karthik L, Rao KV (2013) Phytochemical composition and in vitro antioxidant activity of aqueous extract of Aerva lanata (L.) Juss. ex Schult. Stem (Amaranthaceae). Asian Pac J Trop Med 6: 180-187.

10. Ranju P, Kundlik G, Hitesh G, Thirumoorthy N (2010) Hepatoprotective activity of Beta vulgaris against $\mathrm{CCl} 4$ induced acute hepatotoxicity in rats. Appl Sci Res 2: 14-18.

11. Salvador MJ, Pereira PS, França SC, Candido RC, Ito IY, et al. (2009) Bioactive chemical constituents and comparative antimicrobial activity of callus culture and adult plant extracts from Alternanthera tenella. Z Naturforsch C 64: 373-381. 
Citation: Correa WR, Tasco AJH, Marinho JVN, Pascoal ACRF, Carvalho JE, et al. (2016) Antioxidant and Cytotoxic Activities and Chemical Profile of Five Amaranthaceae Plants Collected in the South of Brazil. Nat Prod Chem Res 4: 230. doi:10.4172/2329-6836.1000230

12. Biella CA, Salvador MJ, Dias DA, Dias-Baruffi M, Crotti LSP (2008) Evaluation of immunomodulatory and antiinflammatory effects and phytochemical screening of Alternanthera tenella Colla (Amaranthaceae) aqueous extracts. Mem I Oswaldo Cruz 103: 569-577.

13. Teixeira CGL, Piccoli A, Costa P, Soares L, Da Silva-Santos JE (2006) Involvement of the nitric oxide/soluble guanylate cyclase pathway in the antioedematogenic action of Pfaffia glomerata (Spreng) Pedersen in mice. J Pharm Pharmacol 58: 667-675.

14. Freitas CS, Baggio CH, Da Silva-Santos JE, Rieck L, de Moraes Santos CA et al. (2004) Involvement of nitric oxide in the gastroprotective effects of an aqueous extract of Pfaffia glomerata (Spreng) Pedersen, Amaranthaceae, in rats. Life Sci 74: 1167-1179.

15. Sanoko R, Esperanza G, Pizza C, De Tommasi N (1999) Triterpene saponins from Alternanthera repens. Phytochemistry 51: 1043-1047.

16. Harbone JB (1998) Phytochemical Methods. A guide to modern techniques of plant analysis, Chapman \& Hall, London.

17. Piccinelli AL, De Simone F, Passi S, Rastrelli L (2004) Phenolic constituents and antioxidant activity of Wendita calysina leaves (Burrito), a folk Paraguayan tea. J Agric Food Chem 52: 5863-5868.

18. Cuendet M, Hostettman K, Potterat O, Dyatmko W (1997) Iridoid glucosides with free radical scavenging properties from fagraea blumei. Helv Chim Acta 80: 1144-1152.

19. Huang D, Ou B, Prior RL (2005) The chemistry behind antioxidant capacity assays. J Agric Food Chem 53: 1841-1856.

20. Ou B, Hampsch-Woodill M, Prior RL (2001) Development and validation of an improved oxygen radical absorbance capacity assay using fluorescein as the fluorescent probe. J Agric Food Chem 49: 4619-4626.

21. Salvador MJ, de Lourenço CC, Andreazza NL, Pascoal AC, Stefanello ME (2011) Antioxidant capacity and phenolic content of four Myrtaceae plants of the south of Brazil. Nat Prod Commun 6: 977-982.

22. Ye M, Han J, Chen H, Zheng J, Guo D (2007) Analysis of phenolic compounds in rhubarbs using liquid chromatography coupled with electrospray ionization mass spectrometry. J Am Soc Mass Spectrom 18: 82-91.

23. Roesler R, Catharino R, Malta L, Eberlin MN, Pastore G (2007) Antioxidan activity of Annona crassiflora: Characterization of major components by electrospray ionization mass spectrometry. Food Chem 104: 1048-1054.
24. Skehan P, Storeng R, Scudiero D, Monks A, McMahon J, et al. (1990) New colorimetric cytotoxicity assay for anticancer-drug screening. J Natl Cancer Inst 82: $1107-1112$.

25. Pietta PG (2000) Flavonoids as antioxidants. J Nat Prod 63: 1035-1042.

26. Rice-Evans CA, Miller NJ, Paganga G (1996) Structure-antioxidant activity relationships of flavonoids and phenolic acids. Free Radic Biol Med 20: 933-956.

27. Soares SE (2002) Ácidos fenólicos como antioxidantes. Rev Nutr 15: 71-81

28. Zocoler AMD, Sanches ACC, Albrecht I, Mello JCP (2009) Antioxidant capacity of extracts and isolated compounds from Stryphnodendron obovatum Benth. Braz J Pharm Sci 45: 443-452.

29. Mazzanti G, Braghiroli L, Tita B, Bolle P, Piccinelli D (1993) Anti-inflammatory activity of Pfaffia paniculata (Martius) Kuntze and Pfaffia stenophylla (Sprengel) Stuche. Pharmacol Res 27: 91-92.

30. Custodio L, Fernandes E, Escapa AL, Fajardo A, Aligue R, et al. (2011) Antioxidant and cytotoxic activities of carob tree fruit pulps are strongly influenced by gender and cultivar. J Agric Food Chem 59: 7005-7012.

31. Salvador MJ, Andreazza NL, Pascoal ACRF, Pereira PS, França SC, et al. (2012) Bioactive Chemical Constituents and Biotechnological Production of Secondary Metabolites in Amaranthaceae Plants, Gomphreneae Tribe. In: Biotechnological Production of Plant Secondary Metabolites, Editor, Ilkay Erdogan Orhan (Ed), Danvers: Bentham Science Publishers 124-158.

32. Carneiro CS, Costa-Pinto FA, da Silva AP, Pinello KC, da Silva TC, et al. (2007) Pfaffia paniculata (Brazilian ginseng) methanolic extract reduces angiogenesis in mice. Exp Toxicol Pathol 58: 427-431.

33. Rao YK, Geethangili M, Fang SH, Tzeng YM (2007) Antioxidant and cytotoxic activities of naturally occurring phenolic and related compounds: a comparative study. Food Chem Toxicol 45: 1770-1776.

34. Choi HJ, Eun JS, Kim BG, Kim SY, Jeon H, et al. (2006) Vitexin, an HIF-1alpha inhibitor, has anti-metastatic potential in PC12 cells. Mol Cells 22: 291-299.

35. Zhou Y, Liu YE, Cao J, Zeng G, Shen C, et al. (2009) Vitexins, nature-derived lignan compounds, induce apoptosis and suppress tumor growth. Clin Cancer Res 15: 5161-5169. 